\title{
COPYRIGHT REVIEW: ISSUES FOR Cultural Practice
}

\section{JILL McKeOUGH*}

The Australian Law Reform Commission (ALRC) has been asked by the Attorney-General to inquire into and report on current and further desirable uses of copyright material in the context of the digital economy. In this paper the focus is on the scope of the terms of reference of the ALRC and the importance of copyright in a modern digitally orientated world. The paper also analyses other important initiatives and reports in this area, focusing on the changing 'political economy' and cultural impact on copyright issues and, in particular the challenges for copyright law.

\section{INTRODUCTION}

On 30 June 2012 the Attorney-General of Australia, the Hon Nicola Roxon MP, asked the Australian Law Reform Commission (ALRC) to inquire into and report on current and further desirable uses of copyright material in the context of the digital economy. ${ }^{1}$ An important part of the background to this Inquiry is the changing 'political economy' surrounding copyright law, where users are demanding a voice in the way that copyright material can be used, and now organise themselves and express their views. Furthermore, it is recognised among cultural communities that 'transformative use' is one form of innovation. At the same time, most people don't want to 'pinch' the creative efforts of others and copyright holders are apprehensive about any 'erosion' of copyright law. The current Inquiry is aimed at trying to find a way through a number of competing considerations as new technology and communications, along with consumer attitudes, are all affecting copyright law.

\footnotetext{
* BA (UNSW), LLB (UNSW), LLM (Syd); Commissioner, Australian Law Reform Commission (ALRC), Copyright and the Digital Economy Inquiry; Professor of Law, University of Technology (UTS), Sydney. Professor Jill McKeough is also Dean of the Faculty of Law at UTS, but is on leave from UTS for the term of the Copyright Inquiry. Much of this paper is drawn from the Issues Paper written by the ALRC Copyright Team: Jill McKeough, Bruce Alston, Jared Boorer, Justine Clarke and Khanh Hoang.

${ }^{1}$ ALRC, ALRC Terms of Reference - Copyright and the Digital Economy (29 June 2012) $<$ http://www.alrc.gov.au/news-media/media-release/terms-reference-received-alrc-copyrightinquiry> ('ALRC Terms of Reference'). The ALRC Terms of Reference are also included in an Appendix to this paper.
} 


\section{New Opportunities for Australian Creators AND INNOVATORS}

In 2011 a Copyright Expert Group produced a statement of fundamental principles of Australian copyright law which recognises 'the importance of encouraging the endeavours of authors, performers and creators by recognising economic rights, ${ }^{2}$ (and also moral rights) 'subject to limitations' ${ }^{3}$ and in a manner which 'takes account of evolving technologies, social norms and cultural values'. ${ }^{4}$ The ALRC Terms of Reference require consideration of how copyright could be assisting where possible in the development of opportunities for Australian creators and not unduly hindering the development of new business models. This is to allow the development of a digital environment which supports the creation of copyright material so that 'rights holders benefit from having a population and economy capable of making productive use of ideas and information, thereby generating the income needed to cover the costs of developing new ideas'. ${ }^{5}$

The ALRC Terms of Reference ask whether amendments to copyright law are required in order to create greater availability of copyright material in ways that will be socially and economically beneficial. Part of the Inquiry is about the most efficient way to achieve this, either through exceptions to copyright without cost to the user - or through statutory licences. The context and political economy of copyright law is changing as copyright has a more direct impact on disparate users and producers, extending beyond rights holders and institutional rights users.

The ALRC Terms of Reference ask the ALRC to look at:

- the adequacy and appropriateness of exceptions and statutory licences and to ensure that Australia's economic and cultural development is supported by these laws; and

- the importance of the digital economy and the opportunities for innovation leading to national economic and cultural development created by the emergence of new digital technologies.

\footnotetext{
${ }^{2}$ Sam Ricketson, Directions in Copyright Reform in Australia (2011) Australian Copyright Council

<http://www.copyright.org.au/pdf/Copyright\%20Council\%20Expert\%20Group\%20\%20Paper\%202011.pdf > .

${ }^{3}$ Ibid 1 [3].

${ }^{4}$ Ibid 1 [4].

${ }^{5}$ Intellectual Property and Competition Review Committee, Report to Commonwealth Minister for Industry, Science and Resources and Commonwealth Attorney General, Review of Intellectual Property Legislation under the Competition Principles Agreement, 2000, 96.
} 


\section{What Does a Successful 'Digital Economy' LoOK LIKE?}

For some time the Australian economy has been recognised as increasingly relying on moving from low-efficiency, labour-intensive industries to highefficiency, knowledge-intensive industries involving cultural goods and services. The 'digital economy' has been defined by the Australian government as 'the global network of economic and social activities that are enabled by information and communications technologies, such as the internet, mobile and sensor networks'. ${ }^{6}$ This includes conducting communications; financial transactions; education; entertainment; and business, using computers, phones and other devices. Australia has competitors in the digital economy, being comparable countries that have also recently adopted a focus on promoting a local digital economy.

Copyright law is an important part of Australia's digital infrastructure and is relevant to commercial, creative and cultural policy. Policy-makers face challenges in managing Australia's transition from resources, agricultural and manufacturing to other drivers of growth.

The current Copyright Inquiry is part of ensuring the Australian environment is able to encourage new opportunities within the digital economy ahead of the National Broadband Network rollout. Copyright should be assisting where possible in the development of opportunities for Australian creators and not unduly hindering the development of new business models. The digital environment should support creation of copyright material so that rights holders benefit from having a population and economy capable of making productive use of ideas and information. In the United Kingdom it has been argued:

- reforms are necessary to increase access to information, knowledge and cultural resources, and to make full use of the opportunities created by new technologies;

- substantial quantities of knowledge are inaccessible;

- there is concern about the limitation of users' rights in the move to digital delivery of works; and

\footnotetext{
${ }^{6}$ Department of Broadband, Communications and the Digital Economy, Australia's Digital Economy: Future Directions (14 July 2009) $<$ http://www.dbcde.gov.au/digital_economy/what_is_the_digital_economy/australias_digital_ec onomy_future_directions $>$.
} 
- copyright is losing credibility in the absence of reforms. ${ }^{7}$

\section{Challenges for Copyright LaW}

Part of the challenge for copyright law is how it might become better understood and more effectively communicated so as to enable Australians to be lawful digital citizens.

Law is not everything. But lawyers tend to consider that it is rather important that it should be obeyed and respected. Otherwise, if it is ignored or defied, that fact might bring down the whole edifice of the rule of law. ${ }^{8}$

Irrelevant laws, which do not fit with community practice and seem incapable of change, are not suitable for assisting in the development of an innovation-based economy. Another challenge therefore is the tension between certainty, predictability of outcomes for established practice and understanding, and the costs of building new understanding in the light of changes to the law.

Copyright law needs to be able to respond to changes in technology, consumer demand and markets. Copyright also needs to have a degree of predictability so as to ensure sufficient certainty as to the existence of rights and the permissible use of copyright materials, leading to minimal transaction costs for owners of users and avoiding uncertainty and litigation.

\section{A Recognising New Ways of Using Copyright Material}

Digital technology has, arguably, been accompanied by changed consumer attitudes to copyright - specifically, less willingness to recognise that copyright is a form of property, owned by a creator (or more usually, the assignee of a creator). Even where copyright is recognised, infringement may be seen as justified. There is a spectrum of 'real world' use which ranges from incidental de minimus use of material to transformative, creative use of material. Clarifying which activities infringe copyright now, and whether certain activity should continue to be categorised as infringement, is part of this Inquiry. One concern is that, at present:

\footnotetext{
${ }^{7}$ Ian Hargreaves, 'Digital Opportunity: A Review of Intellectual Property and Growth' (Report to UK Government Secretary of State for Business and Skills, and UK Government Chancellor of the Exchequer, 2011) 1.

${ }^{8}$ Michael Kirby, 'Foreword' in Brian Fitzgerald and Benedict Atkinson (eds), Copyright Future, Copyright Freedom (Sydney University Press, 2011) 2, 5.
} 
worthy individuals and citizens, many of them children (some maybe even judges), are knowingly, ignorantly or indifferently finding themselves in breach of international and national copyright law. And they intend to keep on doing exactly as before. ${ }^{9}$

Just because many people see a law as irrelevant is not to suggest abolition of that law, or in copyright terms, that that the solution is 'free use' for consumer practices (although it might be). However, means of licensing or exempting what is currently widespread infringement should be considered.

\section{B How to Adapt to the New Environment}

The history of copyright reform has largely been about carving out 'exceptions' and grafting on new rights, including 'neighbouring rights' and the like. The Copyright Act 1968 (Cth) allows for 'exceptions' to copyright law, being certain uses of copyright material without the need for permission or payment. It has been pointed out that 'even in those countries where there is the most vigorous commitment to the advancement of author's rights, it is recognised that there is a need for restrictions or limitations upon these rights in particular cases'. ${ }^{10}$ In Australia these exceptions, or defences to infringement, are for socially useful purposes, including the four long-established exceptions of advancing knowledge through research, commentary by way of criticism or review, reporting news, and the administration of justice. In 2007 fair dealing for the purpose of parody or satire and time and format shifting were introduced. ${ }^{11}$ There are existing exceptions in the Copyright Act that deal with educational use of copyright material, but some concerns exist as to whether these are adequate or appropriate in the digital environment.

\section{Existing Exceptions to Copyright}

Many Australians make copies of copyright material for 'private use', perhaps most commonly, music, television programs and films. In practice, these copies may be stored on and accessed from home computers, personal video recorders, digital discs, portable devices such as smart phones and tablets, and on other devices. Increasingly, copies may be stored on remote computer servers. ${ }^{12}$ There are three types of exceptions now in the Copyright Act that relate to copying for private use, they are format shifting, time-shifting, and making back-up copies.

\footnotetext{
${ }^{9}$ Ibid 4.

${ }^{10}$ Sam Ricketson and Jane Ginsburg, International Copyright and Neighbouring Rights: The Berne Convention and Beyond (Oxford University Press, $2^{\text {nd }}$ ed, 2006) vol 1, 756.

${ }^{11}$ Copyright Amendment Act 2006 (Cth).

${ }^{12}$ ALRC, Copyright and the Digital Economy, Issues Paper No 42 (2012) 26.
} 
Exceptions were introduced to the Copyright Act in 2007 for the 'format shifting' of books, newspapers and periodicals; ${ }^{13}$ photographs; ${ }^{14}$ videotapes; ${ }^{15}$ and sound recordings. ${ }^{16}$. Time shifting was also introduced in 2007 and is allowed under s 111 of the Copyright Act, providing an exception for the making of 'a cinematograph film or sound recording of a broadcast solely for private and domestic use by watching or listening to the material broadcast at a time more convenient than the time when the broadcast is made'. ${ }^{17}$

One policy justification for introducing such exceptions is that Australians routinely make copies for their private use, and do not believe that this should be against the law. The Explanatory Memorandum for the Copyright Amendment Bill 2006, which introduced two important types of exceptions for private copying - time and format shifting — stated that failure to recognise such common practices 'diminishes respect for copyright and undermines the credibility of the Act'. ${ }^{18}$ The Explanatory Memorandum also stated that not recognising such practices is 'unsatisfactory for industries investing in the delivery of digital devices and services'. ${ }^{19}$

\section{2 'User-Generated' Content}

The existing exceptions are narrow, but have served well. Should the copying of legally acquired copyright material be more freely permitted than at present for social, private or domestic use of copyright materials by individuals? The main example of such uses is the uploading and sharing on the internet of noncommercial 'user-generated content' including in social networking. ${ }^{20}$ Usergenerated content may be uploaded onto internet websites by individuals for commercial or non-commercial purposes.

The Organisation for Economic Co-operation and Development (OECD) has defined 'user-created content' as content made publicly available over the internet, which 'reflects a certain amount of creative effort' and is 'created outside of professional routines and practices’. User-generated content includes,

\footnotetext{
${ }^{13}$ Copyright Act 1968 (Cth) s 43C.

${ }^{14}$ Ibid s 47J.

${ }^{15}$ Ibid s 110AA.

${ }^{16}$ Ibid s 109A.

${ }^{17}$ Ibid s 111.

${ }^{18}$ Explanatory Memorandum, Copyright Amendment Bill 2006 (Cth) 6.

${ }^{19}$ Ibid.

${ }^{20}$ Some uses of copyright materials in practices such as back-up copying and format shifting may also be characterised as social, private or domestic uses: see, eg Pamela Samuelson, 'Unbundling Fair Uses' (2009) 77 Fordham Law Review 2537, 2592, discussing 'personal use' copying.
} 
for example, audio-visual excerpts from copyright material, such as movies or music, perhaps associated with commentary by the individual. ${ }^{21}$

While such content may involve creative use of copyright material, the use is not necessarily 'transformative' (as that term is used in the following section), or involve the creation of what may be recognised as cultural works. The Copyright Expert Group observed that user-generated content 'reflects a full spectrum of creative and non-creative re-uses' and should not automatically qualify for protection under any proposed exception aimed at fostering innovation and creativity. ${ }^{22}$

\section{Possible Exceptions to Copyright}

\section{(a) Existing Exceptions Relating to User-Generated Content}

Existing exceptions may apply to some user-generated content using copyright materials, including fair dealing for the purposes of criticism or review; ${ }^{23}$ and parody or satire. ${ }^{24}$ However, much user-generated content will not fit within the ambit of these exceptions - eg, using a copyright sound recording in a home video.

While they may be infringing copyright, individuals who upload copyright material onto social websites — such as YouTube - are not often the subject of legal action by rights holders. Rights holders increasingly work with internet platforms to manage content by other means. For example, in the case of YouTube, rights holders may choose to 'monetize, block or track' the use of their content. $^{25}$

It has been suggested that a new specific exception should be introduced in the Copyright Act to allow individuals to make user-generated content, where this does 'not unjustifiably harm copyright owners' ${ }^{26}$

\section{(b) Transformative Use/Fair Use}

The ALRC Terms of Reference ask the ALRC to consider whether exceptions should allow 'transformative, innovative and collaborative ${ }^{27}$ use of copyright

\footnotetext{
${ }^{21}$ OECD, Participative Web and User-Created Content (2007) 9.

${ }^{22}$ Ricketson, above $\mathrm{n} 2$.

${ }^{23}$ Copyright Act 1968 (Cth) ss 41, 103A.

${ }^{24}$ Ibid ss 41A, 103AA.

${ }^{25}$ YouTube, Content ID (24 July 2012) < www.youtube.com/t/contentid>.

${ }^{26}$ Kimberlee Weatherall, 'Internet Intermediaries and Copyright: An Australian Agenda for Reform' (Policy Paper prepared for the Australian Digital Alliance, 2011) 5.
} 
materials to create and deliver new products and services. The term 'transformative' is used to refer generally to works that transform pre-existing works to create something new and that is not merely a substitute for the preexisting work. Works that are considered transformative may include those described as 'sampling', 'remixes' and 'mashups'. Such uses may be commercial - as in the case of music released commercially that uses samples of existing tracks - or non-commercial, such as where copyright material is used in online user-generated content.

In the United States, transformative use comes under the concept of 'fair use', and the ALRC is specifically asked to consider whether Australian law should recognise 'fair use' of copyright material. ${ }^{28}$ Australian legislation has long provided for exceptions to copyright based on what is understood now to be a closed list of permitted purposes for 'fair dealing' ${ }^{29}$ By contrast, since 1976, the United States legislation has provided for a broad exception to copyright based on an open list of permitted purposes for 'fair use'. ${ }^{30}$ The legislative provisions for 'fair dealing' that are found in countries such as the United Kingdom and Australia, and for the American-style 'fair use' share the same common law source: early English cases that were often concerned with an exception for abridgments. $^{31}$

Commenting on United States law, Professor Pamela Samuelson identifies a number of reasons why 'private and personal uses' of copyright material should either be given a broad scope under American fair use doctrine. These reasons include that private and personal uses:

- generally do not interfere with commercial exploitation of copyright material;

- may be within the 'sphere of reasonable and customary activities' that copyright owners should expect from consumers;

\footnotetext{
${ }^{27}$ See ALRC Terms of Reference, above $\mathrm{n} 1$.

${ }^{28}$ Ibid.

${ }^{29}$ Ibid.

${ }^{30}$ Ibid.

${ }^{31}$ See, eg, William Patry, Patry on Fair Use (West, 2012) 9-10; Matthew Sag, 'The Prehistory of Fair Use' (2011) 76 Brooklyn Law Review 1371; Alexandra Sims, ‘Appellations of Piracy: Fair Dealing's Prehistory' (2011) 1 Intellectual Property Quarterly 3; Megan Richardson and Jason Bosland, 'Copyright and the New Street Literature' in Christopher Arup and William Caenegem (eds), Intellectual Property Policy Reform: Fostering Innovation and Development (Elgar Publishing, 2009) 199, 199; Robert Burrell and Allison Coleman, Copyright Exceptions: The Digital Impact (Cambridge University Press, 2005) 253-64; Copyright Law Review Committee, Copyright and Contract, Report to Commonwealth Attorney-General (2002) 25.
} 
- often involve use of copyright material for the purposes of individual self-expression;

- are generally 'infeasible to regulate' because of the difficulties and costs required to enforce copyright in spaces where these uses often take place; and

- generally preclude the formation of viable markets for copyright licences.

Previous copyright reviews have looked at fair use, but it has not yet been introduced to Australian law. At the time of writing, it is too early to tell what the current mood is with respect to introducing a generalised exception such as this, but certainly there are a range of opinions. While it is true that copyright law needs to respond to changes in technology, consumer demand and markets, it also needs to have a degree of predictability so as to ensure sufficient certainty as to the existence of rights and the permissible use of copyright materials, leading to minimal transaction costs for owners of users and avoiding uncertainty and litigation.

As required by the ALRC Terms of Reference, the Final Report of the Copyright and the Digital Economy Inquiry is to be delivered to the AttorneyGeneral by 30 November 2013. In the meantime, there is much work to be done in talking to stakeholders, observing developments overseas and formulating recommendations for reform.

\footnotetext{
${ }^{32}$ Samuelson, above n 20, 2591.
} 


\section{APPENDIX: ALRC TERMS OF REFERENCE -- COPYRIGHT AND THE Digital ECONOMY ${ }^{33}$}

Having regard to:

- the objective of copyright law in providing an incentive to create and disseminate original copyright materials;

- the general interest of Australians to access, use and interact with content in the advancement of education, research and culture;

- the importance of the digital economy and the opportunities for innovation leading to national economic and cultural development created by the emergence of new digital technologies; and

- Australia's international obligations, international developments and previous copyright reviews.

I refer to the ALRC for inquiry and report pursuant to subsection 20(1) of the Australian Law Reform Commission Act 1996 the matter of whether the exceptions and statutory licences in the Copyright Act 1968, are adequate and appropriate in the digital environment.

Amongst other things, the ALRC is to consider whether existing exceptions are appropriate and whether further exceptions should:

- $\quad$ recognise fair use of copyright material;

- allow transformative, innovative and collaborative use of copyright materials to create and deliver new products and services of public benefit; and

- allow appropriate access, use, interaction and production of copyright material online for social, private or domestic purposes.

\footnotetext{
33 See Ricketson, above n 2.
} 
Scope of Reference

In undertaking this reference, the Commission should:

- take into account the impact of any proposed legislative solutions on other areas of law and their consistency with Australia's international obligations;

- take into account recommendations from related reviews, in particular the Government's Convergence Review; and

- not duplicate work being undertaken on: unauthorised distribution of copyright materials using peer to peer networks; the scope of the safe harbour scheme for ISPs; a review of exceptions in relation to technological protection measures; and increased access to copyright works for persons with a print disability.

Timeframe

The Commission is to report no later than 30 November 2013. 